\title{
ARTŪRAS LUKAŠEVIČIUS
}

Vytauto Didžiojo universitetas, Lietuva

Vytautas Magnus University, Lithuania

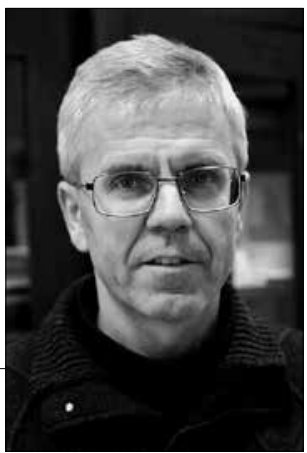

\section{NAUJOJI EVANGELIZACIJA KAIP KATALIKIŠKOS SIELOVADOS PARADIGMA}

\author{
New Evangelisation as Paradigm \\ of Catholic Pastoral Care
}

\begin{abstract}
SUMMARY
The article examines the New Evangelisation that was proclaimed by John Paul II. This evangelization was the group of pastoral activities addressed to dechristianised societies. The article discusses the schemes of Catholic pastoral activities that existed in the course of history and influenced the New Evangelisation. It analyses the essential role of the catechumenate for the education of new Christians in the early Church. In the Middle Ages, after the catechumenate was gradually abandoned because of spread of infant baptism, faith often lacked the dimension of personal decision. The article explores how the mission Ad gentes is used in the New Evangelisation, which becomes a common paradigm for pastoral care in the Catholic Church.
\end{abstract}

\section{SANTRAUKA}

Straipsnyje aptariama Jono Pauliaus II paskelbta Naujoji evangelizacija kaip nukrikščionèjusioms visuomenėms skirta sielovadinių veiklų ir metodų visuma. Nagrinejjamos istoriškai Katalikų Bažnyčioje funkcionavusios sielovadinių veiklų schemos ir jų i̇taka Naujajai evangelizacijai. Parodoma, kaip ankstyvaisiais amžiais gyvavusi katechumenato institucija atliko esminį vaidmenį udant naujus krikščionis. Viduramžiais katechumenatui sunykus dèl visuotinai paplitusio kūdikių Krikšto, tikejjimas dažnai stokodavo asmeniško apsisprendimo dimensijos. Analizuojama, kaip misija Ad gentes naudojama Naujojoje evangelizacijoje, kuri tampa bendra sielovados paradigma Katalikų Bažnyčioje. 


\section{SU İKRIKŠČIONINIMU SUSIJUSI SIELOVADA NUO APAŠTALŲ LAIKŲ IKI VI A.}

Visais laikais Bažnyčia ieškojo tinkamiausių metodų sielovadai, tai yra žmogaus palydèjimui atsivertimo keliu. Žvelgiant i Bažnyčios istoriją kaip i sielovadiniu pastangu ir veiklų istoriją galima išskirti keletą pagrindiniu sielovados modelių.

Apaštalų laikais sielovada vyko pagal tokią schemą: kerigma $\rightarrow$ įtikejjimas $\rightarrow$ sakramentinis įkrikščioninimas $\rightarrow$ katechezè ir kiti sakramentai bendruomenëje (Kavanagh 1991: 22-23). Sielovadinę veiklą šitaip vykdė apaštalai ir jų pagalbininkai skelbdami Evangeliją labai skirtingoms auditorijoms, pvz.: apaštalas Petras Sekminių dieną Jeruzalejje žydams ir kitataučiams judaizmo išpažinëjams (Apd 2, 14-42); apaštalas Petras romeno Kornelijaus namams (Apd 10, 24-48); diakonas Pilypas Etiopijos didžiūnui (Apd 8, 2639); apaštalas Paulius Filipuose pirmiesiems Europos krikščionims (Apd 16, 13-15) ir t. t.

Praejjus keletui dešimtmečiu, Bažnyčia imasi papildyti šią sielovadinių veiklų schemą pradèdama daugiau dèmesio skirti nauju krikščionių formavimui prieš ikkrikščioninimą (Kavanagh 1991: 36). Svarbi priežastis stiprinti tokị formavimą buvo gausūs atsivertimai iš Romos imperijos politeistiniu religijų ir vis mažejjantis iš judaizmo kilusių krikščionių lyginamasis mastas. II a. šis naujų krikščioniu formavimas prieš įkrikščioninimą igauna katechumenato institucijos formą (Laux 1989: 83). Nuo tada keletą amžiu sielovada vykdoma pagal tokią schemą: kerigma $\rightarrow$ įtikèjimas $\rightarrow$ katechumenatas $\rightarrow$ sakramentinis ikkrikščio- ninimas $\rightarrow$ katechezè ir kiti sakramentai bendruomenëje.

Nors katechumenato struktūra įvairiuose regionuose šiek tiek skyrėsi, pagrindiniai jos elementai buvo tie patys. Katechumenatą sudarè keletas laikotarpių ir juos atskiriančiu liturginių žingsnių. Pirmas katechumenato struktūrinis elementas, apie kurị turime pakankamai išsamių žinių, yra prièmimas į katechumenus. Jị sudare keletas vienu pamaldų metu švenčiamu liturginių apeigu, iš kurių pagrindinès yra pažymėjimas kryžiaus ženklu (tikriausiai kaktos), pašventintos druskos įteikimas, rankų uždèjimas ant katechumenu juos laiminant ir egzorcizmo maldos (Yarnold 1994: 4-5). Šiuo pirmuoju žingsniu pradedamas ilgiausiai trunkantis viso pasirengimo tarpsnis - katechumenato laikotarpis ${ }^{1}$. Jo metu kandidatai mokomi tikejjimo tiesu, ugdoma ju morale ir pamaldumas. Rekomenduojama šio laikotarpio trukmè buvo 2-3 metai (Laux 1989: 83), bet dažnai katechumenatas užtrukdavo daugybę metų. Šito priežastis buvo Krikšto atidèjimas vèlesniam amžiui dèl nuodèmès ir sunkių atgailų baimès (Bokenkotter 1990: 45). O katechumenai jau buvo traktuojami kaip Bažnyčios nariai, nors ir nevisateisiai.

Katechumenato laikotarpis baigdavosi, kai kandidatas formaliai įregistruodavo savo varda, o tai buvo laikoma apsisprendimo greitai priimti Krikštą ženklu. Krikštas paprastai būdavo teikiamas Velykų naktí, o prieš tai būdavo kelių savaičiu vadinamasis Apšvietimo laikotarpis. Tai buvo intensyvaus dvasinio ir 
asketinio pasirengimo tarpsnis, kuris sutapdavo su Gavėnia ${ }^{2}$. Jo metu kasdieniuose susitikimuose buvo aiškinamas Tikejjimo išpažinimas ir atliekamos apeigos, iš kurių svarbiausios - egzorcizmai ir dvasios ištyrimai (Yarnold 1994: 9-11).
Visi trys ikrikščioninimo sakramentai būdavo teikiami švenčiant Velykų naktį. Po ikrikščioninimo nauji krikščionys papildydavo savo bendruomenes, kur reguliariai priimant sakramentus tęsdavosi nuolatinio atsivertimo procesas.

\section{SU IKRIKŠČIONINIMU SUSIJUSI SIELOVADA VIDURAMŽIAIS IR NAUJAISIAIS LAIKAIS}

VI a. katechumenato institucija pamažu sunyksta dèl visuotinai paplitusio kūdikių Krikšto. Kadangi kūdikiai nèra pajègūs asmeniškai ir sąmoningai išpažinti tikèjimo, už juos tai Krikšto metu atlieka tèvai ir krikštatèviai, kartu prisiimdami pareigą vaikui augant ugdyti jo krikščioniškajji tikèjimą (Kajackas 1998: 237-238). Todèl asmens sielovada prasideda ịkrikščioninimo sakramentų šventimu. Kartu susiformuoja nauja sielovadinių veiklų išdèstymo schema: kūdikio Krikštas $\rightarrow$ katechezè ir kiti sakramentai šeimoje bei bendruomenëje.

Vaikui augant, jis šeimoje būdavo (ar bent jau turejjo būti) mokomas tikejjimo tiesų ir praktikų. Sulaukęs tuo metu Bažnyčios reikalaujamo amžiaus, jis vietinejje bendruomenèje galèdavo priimti Sutvirtinimo ir Eucharistijos sakramentus. Šalia šių ikrikščioninimo sakramentų isiterpe ir gydymo sakramentas - Išpažintis. Nors šių sakramentų išdèstymas laiko ir vienas kito atžvilgiu patyrė nemažai pokyčiu (Oželis 2005: 38-39), bendra su įkrikščioninimu susijusių veiklų schema išliko ta pati: kūdikystëje prièmęs Krikšta, vèliau vaikas šeimoje ir vietinèje bendruomenèje ruošiasi, priima ir praktikuoja kitus sakramentus (Kajackas 1998: 240-241).
Krikščionybei plintant už Romos imperijos ribų, sielovadinès veiklos buvo organizuojamos laikantis iš esmès tos pačios schemos. Viduramžiais dèl misionierių veiklos ar politinių motyvų Krikštą paprastai priimdavo valdovas, jo dvaras ir visa šalis, o tada būdavo sudaromos sąlygos atvykti vienuolijoms, kurių tikslas buvo mokyti gyventojus tikejjimo tiesų ir praktikų (Schreck 1987: 37). Šiam pirmajam etapui ivvykus, toliau būdavo praktikuojamas kūdikių Krikštas ir sielovada pagal jau aptartą sielovadiniu veiklų organizavimo schemą.

Naujaisiais amžiais atsirado pokyčių misiju kraštuose, kur vèl buvo pradèta taikyti ankstyvojo Bažnyčios laikotarpio sielovados veiklų organizavimo schema: prieš sakramentini ikrikščioninimą vykdavo sielovadinis darbas, kurio tikslas buvo paskelbti ir išaiškinti evangelinę žinią vietiniams gyventojams suprantamu būdu. Taip dirbo misionieriai abiejuose Amerikos žemynuose (šv. Pranciškus Solanus, šv. Turibijus Mongrovietis, šv. Izaokas Žogas ir kt.) bei Azijos šalyse (šv. Pranciškus Ksaveras, Matteo Ricci, Robertas de Nobili ir kt.) (Laux 1989: 467-473). Tačiau ten, kur katalikų tikèjimas îsitvirtino, iš karto būdavo perei- 
nama prie kūdikių Krikšto ir po jo einančios laipsniškos katechezès bei sakramentinio gyvenimo vaikui augant. Ši sielovada išsilaikè kaip vyraujanti Katalikų Bažnyčioje iki II Vatikano susirinkimo.

\section{KVIETIMAS NAUJAJAI EVANGELIZACIJAI}

$X X$ a. sekuliarizmo issigalëjimas ir moralinio bei religinio reliatyvizmo plitimas rodè, kad Bažnyčia turi ieškoti naujų būdų, kaip vykdyti savo sielovadinę misiją (Ratzinger 2000: § I 1). Bažnyčios atsinaujinimui pamatą padejo 1962-1965 m. II Vatikano susirinkimas. Nors Susirinkimo nutarimų igyvendinimas neapsiejo be iššūkių ir problemų, visi vèlesni popiežiai Susirinkimą laikè pagrindiniu atspirties tašku tiek Bažnyčios plačiąja prasme, tiek sielovados, kaip esminès jos misijos, atnaujinimui.

Naujosios evangelizacijos sąvoką pradejjo vartoti ir išplètojo popiežius Jonas Paulius II, tačiau jo pirmtakas Paulius VI atliko labai svarbius parengiamuosius darbus. Apaštališkajame paraginime „Evangelii nuntiandi“ 1975 m. jis visą sielovadą apibūdino kaip evangelizacijos procesa, susidedantị iš îvairių elementų: „Evangelizacija <...> yra daugiasluoksnis procesas, apimantis įvairius elementus: žmonijos atnaujinima, liudijima, tiesiogiai reiškiamą skelbima, vidini pritarima îstojimą ị bendruomenę, ženklų prièmima, pastangas apaštalauti“ (Paulius VI 1975: § 24). Ypač svarbi buvo popiežiaus primygtinè nuoroda, jog evangelizacija yra ne viena iš daugelio Bažnyčios vykdomų veiklų, bet esminè - išreiškianti jos giliausiąją tapatybę: „Evangelizavimas iš tiesų yra <...> tikrasis Bažnyčios pašaukimas, jos gi- liausioji tapatybè. Ji egzistuoja, kad evangelizuotu“" (Paulius VI 1975: § 14).

Jonas Paulius II sąvoką Naujoji evangelizacija pirmą kartą paminejo $1983 \mathrm{~m}$. (Dulles 2006: 5). Nuo to laiko ji tampa vienu svarbiausių jo pontifikatą išreiškiančių šūkių. Naujosios evangelizacijos temą jis išplètojo enciklikoje Redemptoris missio. Čia popiežius išskiria tris skirtingu sielovadinio darbo metodų reikalaujančias situacijas:

Žvelgdami i pasauli evangelizacijos požiūriu, galime išskirti tris situacijas.

Pirmiausia minėtina situacija, kuri yra Bažnyčios misijų veiklos objektas, būtent tautos, žmonių grupès, socialinès bei religinès aplinkos, kur Kristus ir jo Evangelija nèra žinomi arba kur krikščionių bendruomenès nèra pakankamai brandžios, kad galètų ikūnyti tikèjimą savo aplinkoje ir skelbti ji kitoms grupèms. Tai misija ad gentes tikraja šio žodžio prasme.

Antra, yra krikščionių bendruomeniu su tvirtomis bei tinkamomis struktūromis, uoliai tikinčių, gyvenančiu ir spinduliuojančių Evangelijos liudijimu savo aplinkoje ir jaučiančių atsakomybę už visuotinę misiją. Jose vyksta Bažnyčios sielovadinè veikla.

Galiausiai egzistuoja tarpinè situacija, pirmiausia senos krikščioniškosios tradicijos šalyse, tačiau kartais ir jaunesnèse Bažnyčiose, kai ištisos pakrikštytųju grupès yra praradusios gyvo tikèjimo jausmą ar net nebelaiko savęs Bažnyčios nariais ir gyvena toli nuo Kristaus ir jo Evange- 
lijos. Šiuo atveju reikalinga „naujoji evangelizacija“ arba "reevangelizacija“" (Jonas Paulius II 1990: § 33).

Kaip buvo parodyta ankstesniame skyriuje, nuo pat pradžios Bažnyčia suvokè savo sielovadinę veiklą kaip nukreiptą dviem kryptimis: nekrikštyti / netikintieji ir krikštyti / tikintieji. Skyrèsi tapimo „krikštytu / tikinčiuoju“ būdas, bet tiek Romos imperijoje, tiek Viduramžiais Krikštas ir tikejjimas buvo suprantami kaip neatsiejami: krikštytas žmogus yra tikintis, nekrikštytas - netikintis. Šias dvi kategorijas gana tiksliai atitinka pir- moji ir antroji „situacijos“ pateiktoje popiežiaus citatoje. Tačiau pirmą kartą istorijoje kaip svarbi Bažnyčios sielovadinio rūpesčio dalis yra nurodoma trečioji galimybè - krikštyti / netikintieji. Būtent šitoje paradoksalioje „tarpinèje situacijoje" Jonas Paulius kviečia Bažnyčią i Naujają evangelizaciją.

Naujoji evangelizacija kaip Bažnyčios $\mathfrak{i}$ „,krikštytus netikinčiuosius" nukreipta sielovadinè veikla sistemingai aptarta 1997 m. paskelbtame Dvasininkijos kongregacijos dokumente Bendrasis katechezés vadovas.

\section{SIELOVADINĖS VEIKLOS STRUKTÜRA NAUJOSIOS EVANGELIZACIJOS SĄLYGOMIS}

Naujosios evangelizacijos sampratos išeities taškas yra tikslo grupè, ì kurią ji nukreipta: „ištisos pakrikštytųju grupès yra praradusios gyvo tikèjimo jausmą ar net nebelaiko savęs Bažnyčios nariais" (Jonas Paulius II 1990: § 33). Tai yra krikštyti ir dažnai prièmę kitus sakramentus žmonės, kurių pasaulèžiūra ir vertybės mažai kuo skiriasi arba visai nesiskiria nuo nekrikštytųjų. Nors jų priimti sakramentai yra galiojantys, tačiau trūksta sąmoningo ir asmeniško sakramentinès malonès prièmimo. Kaip nurodo Bendrasis katechezés vadovas, tokių žmonių sielovada yra labai panaši i sielovadą misijų kraštuose, kur žmonès apie Kristų ir Bažnyčią nėra nieko girdeję. Skirtumas tas, kad Naujosios evangelizacijos sąlygomis žmonès jau yra prièmę sakramentus, tad jų sielovados užduotis yra padèti jiems sąmoningai bendradarbiauti su jau priimta sakramentine malone.
Misiju kraštuose sielovada vyksta pagal vadinamajji Ad gentes modelị, kurio šiandieninès sampratos pradžia yra II Vatikano dekrete „Dèl Bažnyčios misijinès veiklos Ad gentes". Ši modeli sistemingai aptariantis Bendrasis katechezés vadovas i žmogaus dvasini gyvenimą žvelgia kaip $\mathfrak{i}$ tikejjimo, arba atsivertimo, procesa, susidedanti iš keleto etapu - nuo susidomèjimo tikejjimu iki brandaus isitraukimo i bendruomenès gyvenimą (Dvasininkijos kongregacija 1997: § 47, § 56). Šis dokumentas nurodo, kad Ad gentes yra „pavyzdinis modelis visai Bažnyčios misijų veiklai" (Dvasininkijos kongregacija 1997: $\S 59$ ), taigi ir veiklai Naujosios evangelizacijos sąlygomis (Lukaševičius 2004: 69-76). Bendrajame katechezès vadove aptarti atsivertimo proceso etapai suformuoja naują sielovadinių veiklų išdèstymo schemą: kerigma $\rightarrow$ itikejjimas $\rightarrow$ katechumenatas po Krikšto $\rightarrow$ katechezè ir sakramentai bendruomenëje. 
Susidomèjimas Evangelija yra kerigmos pasekmè (Dvasininkijos kongregacija 1997: § 56). Kadangi Naujoji evangelizacija yra nukreipta $i$ abejingus tikejjimui žmones, kerigma šiomis sąlygomis tampa būtinai reikalingu išeities tašku. Tolesnis kerigmos siekinys yra įtikèjimas arba pirminis atsivertimas, kuris enciklikoje Redemptoris Missio apibūdinamas šitaip: „Atsiversti reiškia asmeniškai apsispręsti priimti išganingą Kristaus viešpatavimą ir tapti jo mokiniu" (Jonas Paulius II 1990: § 46). Suaugusiojo žmogaus itikèjimas yra pamatas, kuriuo remiasi tolesnis krikščioniškas gyvenimas: „Toks "pagrindinis pasirinkimas" padeda pagrindą visam krikščioniškajam Viešpaties mokinio gyvenimui“ (Dvasininkijos kongregacija 1997: § 56).

Kitas etapas yra skirtas tikejjimo pagrindus teikiančiai katechezei: „Savęs atidavimas Jèzui Kristui sužadina tikinčiojo troškimą giliau ji pažinti bei su juo susitapatinti. Katechezė supažindina ji su tikejjimu ir moko krikščioniškai gyventi“" (Dvasininkijos kongregacija 1997: § 56). Kaip aptarta anksčiau, ankstyvai- siais amžiais šią funkciją atlikdavo katechumenatas. Kadangi Naujosios evangelizacijos sąlygomis dirbama su jau pakrikštytais žmonėmis, šiai sielovadinei veiklai nusakyti vartojama kiek paradoksali sąvoka „katechumenatas po Krikšto" (Katalikų Bažnyčios katekizmas 2012: § 1231)³. Kaip paskutini tikèjimo kelionès etapa, kuris truks visą likusi gyvenimą, Bažnyčia nurodo sakramentini gyvenimą krikščioniškoje bendruomenëje:

Kas tikejjimu prigludo prie Jėzaus Kristaus ir savo tikejjimą stengiasi sutvirtinti, privalo gyventi vienybeje su tais, kurie žengia tuo pačiu keliu. Katechezè rizikuoja tapti sterili, jei tikinti ir krikščioniškai gyvenanti bendruomenè nepriima katechumeno tam tikroje savo katechezès stadijoje (Jonas Paulius II 1979: § 24).

Nors ši pastaba pirmiausiai skirta sielovadiniam darbui su katechumenais, ji galioja ir katechumenato po Krikšto atveju. Ittikejusiam žmogui reikalinga tokių pat įtikejjusių bendraminčių, bendrakeleiviu grupelè, kurioje jie kartu galètų mokytis sekti Kristumi.

\section{IŠVADOS}

Sielovada, kaip asmens palydejimas dvasinio augimo kelyje, patyre dideles permainas Bažnyčiai stengiantis ịkultūrinti Evangeliją istorijos tèkmejje. Kadangi pirmiausia Evangelija buvo skelbiama judaizmo išpažinèjams, jiems užteko įtikèjimo i Jèzų Kristų kaip sąlygos priimti ịkrikščioninimą.

Nors apaštalai šią praktiką tęsè ir įtikejjusiujjų pagonių atžvilgiu, netrukus išryškèjo poreikis juos papildomai parengti. Ši parengimą atliko katechume- nato institucija, gyvavusi keletą šimtmečių. Katechumenatas išliko pagrindinè priemoné ginantis nuo nominaliosios krikščionybės pavojaus po krikščionybės legalizavimo ir tapimo valstybine religija IV a. Ši institucija VI a. iš sielovados pamažu eliminuojama perejus prie kūdikių Krikšto.

Viduramžiais ir naujaisiais laikais krikščioniškoji sielovada buvo vykdoma remiantis ne asmenišku apsisprendimu, bet tikejimo kaip kultūrinès tradicijos 
perdavimu šeimoje ir palaikymu valstybèje. Ši tikèjimo perdavimo būdą galutinai sužlugdè naujausių laikų sekuliarizmas, individualizmas ir moralinis reliatyvizmas.

Ieškodama efektyviu sielovados formų naujų iššūkių akivaizdoje, Bažnyčia atsigręžè i savo ištakas. Jono Pauliaus II

\section{Literatūra}

Bokenkotter Thomas. 1990. A Concise History of the Catholic Church. New York: Immage Books Doubleday.

Dulles Avery. 2006. John Paul II and the New Evangelization: What Does It Mean? Martin R., Williamson P. (eds.), John Paul II and the New Evangelization: 2-16. Cincinnati: Servant Books.

Dvasininkijos kongregacija. 1997. Bendrasis kateche$z \dot{e} s$ vadovas. Prieiga per internetą: http://www. lcn.lt/b_dokumentai/vadovai/bendrasis-katechezes-vadovas.html [žiūrèta: 202003 19]

Jonas Paulius II. 1979. Apaštališkasis paraginimas Catechesi tradendae. Prieiga per internetą: http:// www.lcn.lt/b_dokumentai/ap_paraginimai/catechesi-tradendae.html [žiūrèta: 202003 19]

Jonas Paulius II. 1990. Enciklika Redemptoris Missio. Prieiga per internetą: http://www.lcn.lt/b_dokumentai/enciklikos/redemptoris-missio.html [žiūrèta 202003 19]

Kajackas Algimantas. 1998. Bažnyčia liturgijoje. Liturgijos raida istorijoje. Kaunas: LKB TKK.

Kataliku Bažnyčios Katekizmas. 2012. Vilnius: Katalikų pasaulio leidiniai.

Kavanagh Aidan. 1991. The Shape of Baptism: The Rite of Christian Initiation. Collegeville: The Liturgical Press.

Laux John. 1989. Church History. A Complete His-

\section{Nuorodos}

1 Painiavą gali sukelti termino katechumenatas vartojimas dviem skirtingomis, nors artimai susijusiomis prasmėmis: pirmu atveju katechumenatas reiškia visą ikrikščioninimo procesa, susidedanti iš keleto žingsnių ir laikotarpių, antru atveju reiškia vieną iš šio proceso sudedamųju dalių - katechumenato laikotarpi.

2 Gavėnios trukmè ankstyvojoje Bažnyčioje smarkiai kaitėsi. Žr. Šulcienė 2019: 78. paskelbta ir vèlesniuose Bažnyčios dokumentuose išplètota Naujosios evangelizacijos samprata daugeliu atžvilgiu atgaivina ankstyvųjų amžiu sielovados metodus. Kartu ji suteikia struktūrą sielovadinès veiklos formų visumai ir tampa bendra sielovados paradigma Katalikų Bažnyčioje šiandien.

tory of the Catholic Church to the Present Day. Rockford: Tan Books and Publishers, Inc.

Lukaševičius Artūras. 2004. Ad gentes modelio taikymas šiandienos jaunimo pastoracijoje Lietuvoje, Soter 12 (40): 69-76.

Oželis Remigijus. 2005. Vaiku ikrikščioninimo plètra Lietuvoje: metodai ir veiklos formos. Daktaro disertacija (humanitariniai mokslai, teologija $02 \mathrm{H}$ ). Kaunas: VDU.

Paulius VI. 1975. Apaštalinė adhortacija Evangelii Nuntiandi. Prieiga per internetą: http://www.lcn. lt/b_dokumentai/ap_paraginimai/evangelii_ nuntiandi.html [žiūrèta: 202003 19]

Ratzinger Joseph. 2000. Naujoji evangelizacija, Bažnyčios žinios 2, 2001. Prieiga per internetą: http:// www.lcn.lt/bzinios/bz0102/102dok4.html [žiūrèta: 202003 19]

Suaugusiuju įkrikščoninimo apeigos. 2016. Vilnius: Kataliku pasaulio leidiniai.

Schreck Alan. 1987. The Compact History of the Catholic Church. Ann Arbor: Servant Books.

Šulcienè Lina. 2019. Disciplina arcani praktikos priežastys pagal Kirilo Jeruzaliečio katechezes, Logos 101: 77-84.

Yarnold Edward. 1994. The Awe-Inspiring Rites of Initiation. The Origins of the RCIA. Collegeville: The Liturgical Press.

3 „Katechumenato po Krikšto“ sampratos formavimuisi ypatingą reikšmę turèjo Krikšto katechumenato institucijos atnaujinimas Kataliku Bažnyčioje po II Vatikano susirinkimo. Jo struktūrą ir eigą aprašo $1972 \mathrm{~m}$. popiežiaus Pauliaus VI patvirtintas apeigynas Ordo initiationis christianae adultorum. Šventojo Sosto patvirtintas lietuviškas šio apeigyno vertimas Suaugusiuju ikrikščoninimo apeigos išleistas $2016 \mathrm{~m}$. 